\title{
THE VALUE-BASED PRICING DETERMINATION MATRIX FOR PRICING METHOD SELECTION
}

\author{
Steinbrenner, F., Turčínková, J.
}

Florian Steinbrenner / Mendel University in Brno, Faculty of Business and Economics, Department of Marketing and Trade, Zemědělská 1, 61300,Brno, Czech Republic. Email: flo.steinbrenner@gmail.com Jana Turčínková / Mendel University in Brno, Faculty of Business and Economics, Department of Marketing and Trade, Zemědělská 1, 61300, Brno, Czech Republic. Email: jana.turcinkova@mendelu.cz

\begin{abstract}
Several researchers suggest that value-based pricing (VBP) is one of the most profitable pricing methods for companies competing in today's business environment. Interestingly, the implementation rates of VBP are, however, rather low. Numerous barriers to the implementation of value-based pricing have been found by researchers already. Although, a theoretical model for determining whether value-based pricing may be a suitable pricing method for a business is yet to be found in the literature. This study aims to introduce a theoretical model to aid pricing executives in their pricing method selection.

For this purpose, 20 semi-structured in-depth expert interviews with German pricing experts were conducted as part of qualitative data analysis. The experts were selected using a purposive selection method. Pricing experts were asked to describe the most important factors for determining whether a company may implement value-based pricing.

We identified two main factors as being necessities for using VBP. The first factor named by the authors was the brand advantage (BA), and the second factor was represented by the delivered product benefits (DB) as perceived by the customer. Based on these two factors, a two-dimensional, quadrant-based theoretical model was developed and was named the VBP Determination Matrix. The matrix now evaluates a company's position within the matrix based on the factors BA and DB. It leads to direct calls-to-action for properly choosing the most suitable pricing method. This study's theoretical contribution was the development of a so far non-existing two-dimensional model for the determination of the suitability of value-based pricing. Business practitioners are now provided with an easy-to-use and highly applicable model to determine the initial suitability of implementing VBP. Senior management is given direct calls-to-action, whether an investment to implement VBP shall be made and whether to allocate resources.

Implications for Central European audience: The VBP Determination Matrix is a highly applicable model recommended especially for business practitioners in pricing, marketing and management. Central European companies are recommended to utilise the model to benefit from its strategic recommendations to properly select the most suitable pricing method for profit maximisation and competitiveness optimisation.
\end{abstract}

Keywords: implementation; model; price-setting; strategy; value-based pricing JEL Classification: L11, D46 


\section{Introduction}

This research study brings together current literature on value-based pricing and the most prominent issues in implementing it. Most of the Central European literature on the topic of value-based pricing has focused on definitions and identification of the difficulties with the implementation stage of this pricing method (e.g. Anderson et al., 2010; Hinterhuber, 2008a; Hinterhuber \& Bertini, 2011; Hinterhuber \& Liozu, 2012; Michel \& Pfäffli, 2012; Nagle et al., 2011; Nagle \& Müller, 2018; Töytäri et al., 2015, p. 54; Töytäri et al., 2017; Reynolds, 2018). A framework or guideline to predict the overall necessity or potential for successful implementation of value-based pricing lacks so far. This is a striking aspect, considering that most literature has assumed that value-based pricing shall generally be implemented and, thus, has focused on the implementation stage with its aligned issues (e.g. Codini et al., 2012; Michel \& Pfäffli, 2012; Töytäri et al., 2017). Some researchers have confirmed the lack of research in this field: Chenavez and Paraschiv $(2018$, p. 2) found a lack of research for VBP pricing models and stated that "(n)ew dynamic pricing models need to be developed that also address [...] actual consumer behaviour." In addition, Töytäri et al. (2017, p. 245) encouraged that "research could investigate several [...] industries" to take a cross-industry perspective on implementing value-based pricing. Particularly, the planning and determination stage before the actual implementation seems to be underestimated. Potential profitability and usefulness could be identified before starting the implementation stage if a framework or model was available to business practitioners. In this case, usefulness is not confirmed through such a framework; resources may be invested alternatively.

Thus, this paper aims to introduce such a theoretical model that is applicable across different industries to aid business practitioners in determining the initial suitability and usefulness of value-based pricing implementation. As "Germany is a representative European traditional market economy" (Jerman et al., 2010, p. 61), German pricing experts with international experience across Central Europe were asked about their perceptions and experiences of value-based pricing and its implementation in business practice to address this objective.

\section{Theoretical background}

\subsection{Pricing methods}

Pricing represents one of the strongest revenue-generating factors while being underestimated in several cases (Bruck, 2010; Baker et al., 2010). According to Simon and Fassnacht (2016), the main profit drivers are mainly price, quantity, and costs. Within the factors of the marketing mix - product, place, promotion, people and price - the latter factor has received the least research in literature and researchers have investigated the first four factors more intensively (e.g. Harris, 1994; Harvey, 1993; Hill \& Still, 1984; Rosenbloom et al., 1997; Walters \& Toyne, 1989). This is an interesting observation, as usually enormous resources are required to change factors within the marketing mix, except the factor price that can be changed easily and effectively (Bosankic, 2016). Recent research has confirmed that pricing is "often an undermanaged process in many firms" (Homburg et al., 2015; in Hofer et al., 2019, p. 74). What is crucial for companies to comprehend is that "a firm's pricing is a key marketing capability and crucial success factor" (Hofer et al., 2019, p. 74). Further, an "increased complexity" with a "large number of variables that influence [...] pricing" is existent (Hofer et al., 2019, pp. 74-75). As Neubert (2017, p. 48) concluded, there is a "need to implement efficient price-setting processes, strategies, practices and models in the 
organisation with the intention to review pricing decisions regularly and to react early and fast on new market information."

Taking a deeper look into pricing and its already defined methods, mostly cost- and competition-based pricing were the most frequently implemented and most commonly used pricing methods (Hinterhuber, 2008a). However, researchers identified a lack of value reflection within both of these pricing methods (Guerreiro \& Amaral, 2018, p. 394). Further, Frohmann (2018, p. 75) emphasised several risks with cost-based pricing, such as potential loss of market share if expected profit margins are too high or that the focus is too much on internal aspects of a company. For competition-based pricing, one company's price increases or decreases may lead to competitive responses with consequences that were often referred to in Game Theory literature (Dixit \& Nalebuff, 2019; Frohmann, 2018; Simon \& Fassnacht, 2016). Potential risks in competition-based pricing include the erosion of profit margins through constant competitor underbidding (Frohmann, 2018, p. 79; Hielscher \& Firlus, 2018; Schuldt, 2018;). A pricing method where these disadvantages are circumvented has recently emerged in the form of value-based pricing.

\subsection{Value-based pricing}

Value-based pricing has increasingly gained both research attention and practitioners' interest (Slywotzky, 1996). Researchers identified value-based pricing as the most profitable pricing method (Hünerberg \& Hüttmann, 2003; Piercy et al., 2010). However, only a small number of companies actively implemented value-based pricing (Hinterhuber \& Bertini, 2011). Increased profitability and enhanced competitiveness may be generated by improving the pricing strategy and using the most profitable pricing method value-based pricing.

The increasing attention that VBP has received by researchers was initially explained by Slywotzky (1996), believing that more successful pricing outcomes can be generated by using value-based pricing. Researchers Cannon and Morgan (1990, p. 22) defined VBP by mentioning that the "approach involves pricing on the basis of the monetary value a product has for target customers. It is a demand-oriented method which assumes that a firm can determine what people are willing to pay for a product and its various forms". Ding (2007, p. $7)$ added to that definition that "( $(v)$ alue-based pricing is an important conceptual approach [...] that leverages the benefits of the service offering in order to match the buyer's willingnessto-pay with the value received". Being considered the most profitable pricing method available (Hünerberg \& Hüttmann, 2003; Piercy et al., 2010), VBP is seen as a superior method to determine prices and increase its competitiveness. Anderson et al. (2010) and Terho et al. (2012) stated that a positive sum-game is created with VBP, as the pricing method is favourable to the buyer and the supplier. Further, researchers believed that creating customer value is connected to achieving strong business performance and success (Blois \& Ramirez, 2006; Gosselin \& Bauwen, 2006). More recent research added that pricing products or services should always be conducted while reflecting the customer perceived value (Nagle \& Müller, 2018). It is also believed that marketing efforts may lead to a higher customer perceived value, increasing effectiveness with VBP as a consequence (Reynolds, 2018). 


\subsection{Issues in implementing value-based pricing}

In a study conducted by Hinterhuber and Bertini (2011, p. 47), it was found that value-based pricing was much less implemented in comparison to other pricing methods. Further, several obstacles to the implementation of value-based pricing were identified by researchers and impede the usage of the most profitable pricing method. Value-based pricing is often seen as a much more complex approach to pricing products or services than other pricing methods like cost- or competition-based pricing (Liozu et al., 2012a; Nenonen \& Storbacka, 2010; Töytäri et al., 2017).

Hinterhuber (2008a) and Hinterhuber and Bertini (2011) found that the main barriers in implementing value-based pricing are the difficulties in assessing value, communicating value, market segmentation, sales force management and senior management support. Dittmer (2017) mentioned that the danger of losing customers was another obstacle to the implementation of value-based pricing. Forbis and Mehta (1981) stated that high customer specificity makes an implementation complicated. Further, the habit of using traditional pricing methods (Hinterhuber, 2008a; Hinterhuber, 2008b; Indounas, 2009; Kienzler, 2018; Kurz \& Többens, 2012; Liozu et al., 2012b; Liozu, 2017; Töytäri et al., 2015), the lack of experience and skills (Töytäri et al., 2017), the lack of support from top management (Hinterhuber, 2008a; Hinterhuber \& Bertini, 2011; Liinamaa et al., 2016, pp. 42-43; Liozu et al., 2012b; Tohamy \& Keltz, 2008) and the lack of motivation of the respective department (Nagle \& Hogan, 2007; Töytäri et al., 2015; Töytäri et al., 2017) all represent further obstacles.

Recent studies have further focused on cognitive biases and phenomena, inhibiting a successful implementation of VBP, such as the 'fixed-pie bias' or 'egocentric fairness bias' (Kienzler, 2018). Hague (2019, online) further discussed that customer surveys are often needed to properly identify the customer perceived value of products or services. He focused on the conjoint analysis and states that the "problem for business researchers until now has been the cost of carrying out conjoint analysis. In order to arrive at reliable results, it is necessary to carry out at least 100 interviews, and we feel more comfortable with 200 or more. [...] Think 200 face to face interviews scattered across Europe and you are thinking $€ 300,000+$ survey cost. For many companies, this will break the market research budget".

As it is later emphasised in detail in the results section, this research study found that the two factors: 1. brand advantage and 2. product benefits are of significant relevance for the model to be created. Both of these two factors need to be evaluated with assessment criteria from existing research. Therefore, the following two subchapters are dedicated to reviewing the evaluation criteria for these two factors. The results section will later dive deeper into using the information based on the discussed assessment criteria from existing literature.

\subsection{Assessing brand advantage}

Park and Srinivasan (1994, p. 271) defined brand equity as an "added value endowed by the brand to the product as perceived by a consumer". Keller (1993, p. 2) rather explained brand equity as a "differential effect of brand knowledge on consumer response to the marketing of the brand". Subhani and Osman (2009, p. 3) mentioned that brand equity mostly is "built by laying a foundation of brand awareness".

According to Aaker (1996), brand awareness is based on the brand's perception in the consumer's mind. He further mentioned that there are different levels of how much a customer 
may remember a brand. These levels included brand recognition, brand recall, top-of-mind brand and dominant brand. Brand recognition was based on how strongly consumers can actively confirm that they were previously exposed to a given brand name. Brand recall rather meant a customer's ability to remember the brand based on their memory when a product category is provided. The top-of-mind brand was related to the first reaction or first response a consumer gets in stating a brand name when they were shown a certain product. Lastly, dominant brand referred to the fact that consumers needed to provide one single brand name based solely on memory, and if they recalled the correct brand name, a very high awareness level was achieved (Aaker, 1996).

In a study conducted by Molinillo et al. (2018), a 'Consumer-Based Brand Performance Model' (CBBPM) was introduced to measure how successful a brand is. The study determined that the factors "brand equity, brand satisfaction and brand trust are prominent variables in explaining brand loyalty" (Molinillo et al., 2018, p. 16). For their study, 435 respondents participated in a survey about customer's perceptions of different brands. They were asked about their choice of the brand they were familiar with when given different brands. Molinillo et al. (2018) then found that consumer-based brand equity (CBBE) has a positive influence on brand satisfaction, brand trust as well as brand loyalty and, in conclusion, that increased brand equity increases success.

To successfully measure brand equity, Aaker (1996, p. 103) defined "The Brand Equity Ten", which are "ten sets of measures grouped into five categories" (Aaker, 1996, p. 105). These categories are the type of measure to assess the brand awareness and equity of a company. A company can use these ten measures to self-evaluate their company's perceived brand image among consumers. For this purpose, consumer studies are needed and should be based on the following ten measures based on Aaker (1996, pp. 106-116).

For this purpose, in the first step, customers should be asked about ...

i. $\quad$... their additional willingness-to-pay for the particular brand (price premium)

ii. $\quad$... their satisfaction with the last purchase of a product from that brand (satisfaction)

iii. ... their perceived quality of the brand compared to other brands on a high-mediumlow scale (perceived quality)

iv. $\quad . .$. their perception of the leading brand vs. not one of the leading brands (leadership \& popularity)

v. $\quad .$. whether the particular brand provides value for the price (perceived value)

vi. ... whether the brand is perceived as interesting and is perceived to have a personality (brand personality)

vii. $\quad . .$. whether the organisation behind the brand is perceived as a trusted and admired brand (organisational associations)

In a second step, an awareness test with customers can be conducted by testing ...

viii. ... their level of brand awareness (recognition, recall, top-of-mind and others) in different tests (brand awareness)

In the third step, market measures shall be investigated by comparing ...

ix. $\quad . .$. market share and company performance on the market (market share) 
x. ... relative market price by obtaining "prices of several varieties of the brand weighted by their relative sales volume" (market price and distribution indices; Aaker, 1996, p. 116)

\subsection{Assessing product benefits}

"What are your products and services actually worth to customers? Remarkably few suppliers in business markets are able to answer [...]" this question (Anderson \& Narus, 1998, online). Anderson and Narus (1998, online) further stated that knowing the value a product or service delivers to consumers becomes increasingly crucial for businesses. The researchers further added in the same research study that more and more companies use "customer value models, which are data-driven representations of the worth, in monetary terms, of what the supplier is doing or could do for its customers". Anderson and Narus (1998, online) emphasised that it was crucial to create "a comprehensive list of value elements" to "be able to gauge more accurately the differences in functionality and performance" of the product or service in comparison to competitive market offerings. Halttunen (2016) added to that research by identifying that in today's digital markets, emerging factors like the ease of use, access to the service, consumer's technological skills or consumer's trust need to be added to the existing factors price, quality and choice variety to determine the product benefits to consumers properly.

For quantifying the perceived delivered benefits of a product or service to a target customer, Forbis and Mehta (1979) emphasised the concept of 'Economic Value to the Customer' (EVC). Tucker (2010, p. 1) stated that EVC mostly "is based on the insight that a customer will buy a product only if its value to them outweighs the value of the closest alternative". Based on Anderson and Narus (1998) and Tucker (2010), a company may evaluate all valuegenerating factors of a market offering and calculate the differentiated value of all individual factors to add them then together. As such, the EVC helps determine the perceived delivered benefits of a product $a$ in comparison to the closest alternative, product $b$. The following two formulas need to be considered.

Differentiation value $(a b)=$ Value $(a)-$ Value $(b)$

EVC $(a)=$ "Differentiation Value" $(a b)+$ "Reference Price"

where:

- Differentiation Value $(a b)=$ Net value gained for the customer when deciding for product $a$ instead of product $b$

- $\quad$ Value $(a)$ = value gained by the customer through product $a$

- Value $(b)=$ value gained by the customer through product $b$.

- $\quad E V C=$ Economic value to the customer

- Reference Price $=$ Price of closest competitor's product, in this case price (product b)

When the differentiation value $(a b)$ is calculated, this gives a major guideline to a company to understand the delivered benefits of the product or service as perceived by a target customer. 


\section{Research objective, data and methods}

\subsection{Research objective and research question}

The obstacles to implementing value-based pricing can hardly be grouped, segmented or even generalised for individual industries or individually acting companies in any industry. Research has mainly focused on finding obstacles to implementing value-based pricing for one specific industry, and these obstacles may not even be applicable to all companies in that specific industry and certainly not to companies from entirely different industries. Thus, a theoretical framework for business practitioners to determine the potential for success with value-based pricing for individual companies lacked in today's literature. This research study's objective was to address this research gap by developing and introducing a new theoretical framework or model that aids business practitioners in the field of pricing with the selection of a suitable pricing method. The new model should be clearly defined, easy to use and highly applicable for senior management in companies across all industries in the Central European region. Based on this research objective, the research question was stated as the following.

$R Q$ : What new theoretical framework can be developed to aid business practitioners in the choice of a suitable pricing method and to determine whether they should implement valuebased pricing?

\subsection{Methodology}

For this research study, a mono method qualitative research design was used, based on the definition by Saunders and Tosey (2013, pp. 58-59), who state that "(r)esearchers can choose to use a single data collection technique and corresponding analysis procedure, either a mono method quantitative design (for example, data collected using a questionnaire, analysed statistically) or a mono method qualitative design (for example, data collected through in-depth interviews, analysed as narratives)." In order to achieve the objective of this research study and to be able to respond to the stated research question $R Q$, qualitative data was needed. That is because the expertise of pricing managers and pricing consultants was needed to benefit from practical knowledge and realistic examples from the interviewees' daily business to develop a model that would be highly beneficial for business practitioners.

Flick et al.'s (2008) research confirmed that qualitative data is most useful for investigating the interviewees' daily business. A collection of quantitative data such as consumer surveys based on their willingness-to-pay or value perceptions would not have led to the proper development of a theoretical model or matrix needed for this objective. Realistic business examples were not identified. Semi-structured interviews (SSI) were used intentionally, as "the SSI employs a blend of closed and open-ended questions, often accompanied by followup why or how questions. The dialogue can meander around the topics on the agenda rather than adhering slavishly to verbatim questions as in a standardised survey - and may delve into totally unforeseen issues" (Newcomer et al., 2015, p. 493).

Moreover, a grounded theory methodology was used to develop a new theory. Strauss and Corbin (1994, p. 273) defined grounded theory as "a general methodology for developing theory that is grounded in data systematically gathered and analysed. Theory evolves during actual research, and it does this through continuous interplay between analysis and data 
collection." Based on the definition stated, this methodological approach seemed to be most promising to respond to the research question stated. Based on these definitions, a mono method qualitative research approach was used based on a grounded theory methodology (Strauss \& Corbin, 1994) by conducting 20 semi-structured interviews with German pricing experts. This research approach most appropriately addressed the objective and research question stated in chapter 2.1.

The industry focus was intentionally chosen to be broad. Four relatively large industries were chosen for this study to generalise results on a cross-industry basis. So far, researchers have mainly focused on the implementation of value-based pricing in the pharmaceutical industry (Dittmer, 2017; Provines, 2010), the travel \& tourism industry (Collins \& Parsa, 2006; Hung et al., 2010), the technology industry (Kienzler, 2018; Liinamaa et al., 2016; Töytäri et al., 2015) and the consumer goods industry (Codini et al., 2012). Therefore, these four industries were taken as the focus of this study to generate a theoretical model that can be transferred and generalised for more than one industry. Thus, all interviewed pricing experts worked in one of these four industries at the time of the interview.

\subsection{Data collection and sample}

The sample of this qualitative research study consisted of 20 German pricing experts from the four analysed industries mentioned in chapter 2.2. The experts were selected using a purposive selection method. The interviewed pricing experts were either pricing consultants with their clients being end customers (or companies in B2B markets) from one of the four industries analysed, or directly pricing representatives from industrial, producing or servicedelivering companies. The qualitative data was collected in spring 2020.

Based on online research through Linkedln, Xing and Google Search, German pricing experts were found and contacted. The requirement to qualify as a pricing expert for this study was expertise in pricing at least five years and employment at a company out of one of the four industries analysed. In total, 33 experts were contacted, out of which 20 experts agreed to an interview; because of the physical distribution of experts across Germany and limitations due to coronavirus precautions, the telephone interview approach needed to be chosen. A sample size of 20 was used because after the first 10 to 12 interviews; results started to overlap very frequently. Thus, it is likely to state that interviewing more pricing experts than 20 , results were very likely to further overlay and would have led to very similar conclusions.

For this study, results from the collected qualitative data analysis were used. The qualitative data was analysed using Mayring and Brunner's (2007) qualitative content analysis. Data was collected in German language, recorded, coded by topic and context in MAXQDA, and then translated into English. A regular interplay between data collection and data analysis was utilised, reflecting a grounded theory methodology (Strauss \& Corbin, 1994). The 20 indepth interviews serve as the basis for this research study. Table 1 illustrates the experts interviewed and their area of expertise, and their industry as the sample chosen. 
Table 1 | Overview of interviewed experts

\begin{tabular}{clll}
\hline Expert & Industry & Company type & $\begin{array}{l}\text { Company size by } \\
\text { number of } \\
\text { employees }\end{array}$ \\
\hline 1 & Pharmacy & Consulting & 50 \\
2 & Retail & Consulting & 1,000 \\
3 & Technology & Industry & 140,000 \\
4 & Retail & Consulting & 600 \\
5 & Technology & Consulting & 70 \\
6 & Technology & Consulting & 40 \\
7 & Retail & Consulting & 50 \\
8 & Technology & Consulting & 20 \\
9 & Technology & Consulting & 5 \\
10 & Travel \& Tourism & Consulting & 5 \\
11 & Travel \& Tourism & Consulting & 12 \\
12 & Pharmacy & Industry & 75 \\
13 & Technology & Industry & 25 \\
14 & Technology & Industry & 10 \\
15 & Retail & Industry & 1,500 \\
16 & Retail & Industry & 105 \\
17 & Pharmacy & Industry & 60,000 \\
18 & Travel \& Tourism & Industry & 1,500 \\
19 & Travel \& Tourism & Industry & 750 \\
20 & Pharmacy & Industry & 120 \\
\hline
\end{tabular}

Source: authors' qualitative data collection $(n=20)$

The questionnaire, consisting of 23 questions in total, was sent to all interviewees seven days before the arranged interview was conducted. The questions that mainly led to the results of this research study were the following four questions.

1) Based on your perception, what is most important in price determination nowadays?

2) How do people decide how much they are willing to pay for a product or service, what is important to them?

3) How do you consider the relevance of value-based pricing in business practice?

4) What are the most important factors for the implementation of value-based pricing?

Each of these four questions was given at least one code in MAXQDA as part of the coding stage during the data analysis, which was conducted in German language and later translated into English for this research paper. Based on the qualitative content analysis utilised and the codes used in MAXQDA, this research study's results were derived.

\subsection{Reliability and validity of the study}

Lincoln \& Guba (1985) emphasised in their research that reliability and validity were mainly criteria that are of high relevance in quantitative research, while qualitative research rather necessitated criteria like credibility, neutrality, confirmability or transferability. According to Golafshani (2003, p. 601), the "examination of trustworthiness is crucial." In this research study, the interviewer collected, reported, and dealt with the data trustworthily and securely. Leung (2015) stated that reliability mainly necessitated consistency in qualitative research 
approaches. Stenbacka (2001, p. 552) raised an interesting point in stating that "the concept of reliability is [...] misleading in qualitative research. If a qualitative study is discussed with reliability as a criterion, the consequence is rather that the study is no good." Lastly, Lincoln \& Guba (1985, p. 316) mentioned that ensuring validity in a qualitative study further establishes its reliability as a consequence.

For validity in qualitative research studies, literature has provided ambiguous definitions. Golafshani (2003, p. 603), for instance, stated that "the quality of a research is related to generalizability of the result and thereby to the testing and increasing the validity or trustworthiness of the research." Patton (2002) further confirmed the relevance of generalizability of findings to enhance validity in qualitative research studies. Creswell \& Miller (2000, p. 126) identified that validity could be enhanced by searching "for convergence among multiple and different sources of information to form themes or categories in a study." Golafshani (2003, p. 604) stated that "reliability (as well as) validity are conceptualised as trustworthiness, rigor and quality in qualitative paradigm." Leung (2015) further mentioned that the tools and processes' appropriateness was crucial for determining quality in qualitative research studies. One interesting research finding was found in Kitto et al.'s (2008) research, where six main criteria for assessing quality in qualitative research were found. These six criteria were clarification and justification, procedural rigour, sample representativeness, interpretative rigour, reflexivity and generalizability. This research paper and its validity shall be assessed by using these six criteria for validity in qualitative research.

First, the clarification and justification referred to "clarity of research question reflected in the aims of the study" (Kitto et al., 2008, p. 244). The research question employed was stated clearly, unambiguous while reflecting the research study's objective. Respondents didn't request any further explanations and comments to the given questions. Thus, clarification and justification of this research paper are validated.

Second, procedural rigour was described as the "transparency or 'explicitness' of the description of the way the research was conducted" and deals with information about the data collection and how it was analysed (Kitto et al., 2008, p. 244). In this research paper, transparency was given based on the clear description of the data collected, how the data was recorded, transcribed, coded, translated and analysed using Mayring and Brunner's (2007) qualitative content analysis. Thus, the procedural rigour of this paper is validated.

Third, representativeness rather referred to the type of sampling approach and whether it is representative for the study (Kitto et al., 2008, p. 244). In this research study, the maximum variation sampling approach was used, as the representativeness of all aspects of the topic in terms of participants was sought with experts interviewed. The differentiation was taken between industries and between experts' professions, having been either pricing consultants in a consulting company or pricing managers in an industrial company. As responses further overlapped frequently, it is likely to state that results were representative of Central European countries' industries. The representativeness of this study can, thus, be validated.

Fourth, interpretative rigour should be ensured by "a clear description of what forms of analysis were used, the process and what were the major outcomes of the analytical process in terms of findings" (Kitto et al., 2008, p. 245). The form of analysis was clearly described in this research study, along with the analytical procedure utilised as well as the results found from the investigation. Thus, interpretative rigour is validated. 
Fifth, Reflexivity "requires a demonstration by the researchers that they are aware of the sociocultural position they inhabit and how their value systems might affect the selection of the research problem, research design, collection and analysis of data" (Kitto et al., 2008, p. 245). The authors are aware that their sociocultural position may impact research results. One of the limitations referred to in the discussion section is the possible biased perceptions of the first author based on his professional background as a pricing manager. An objective perspective was sought for this research study. However, subconscious biases may never be fully denounced. For this research study, the objective perspective and reflective acknowledgement of the influence of own value systems lead to the validation of reflexivity.

Sixth, "(c)onceptual generalizability and transferability refer to how well the study's findings inform [...] contexts that differ from that in which the original study was undertaken" (Kitto et al., 2008, p. 245). Based on the research approach taken, with experts from pricing consulting and pricing executing companies, as well as experts being from four different industries, a wide range of experts was interviewed. As responses frequently overlaid and supplemented responses from other interviews, generalizability and transferability were determined for business practitioners in the Central European region. Further, the VBP Determination Matrix was intentionally set to be a generalisable model for senior pricing managers across industries. Thus, generalizability and transferability for this research paper can be validated.

The six criteria based on Kitto et al.'s (2008) research were fulfilled and led to the validation of the research approach taken.

\section{Results}

According to the majority of experts interviewed, a major challenge in implementing VBP in business practice is to determine whether VBP may be a possible alternative to the often already utilised cost- and competition-based pricing. In other words, companies are often aware of VBP but do not comprehend whether it may be a relevant pricing method for their company. To increase competitiveness and profitability among companies in the field of value-based pricing, a relevant tool was lacking so far. Based on the results of the first 12 interviews out of the 20 interviews conducted, two individual factors were mentioned very frequently, which increase the potential of success with VBP.

1) VBP implementation is more likely successful if the company has an advantage due to its positively perceived brand image on the market. Some experts described this as the following:

- $\quad$ Expert 2: "Starbucks, Louis Vuitton, these are brands with an incredibly good brand image. Their products are high quality, sure, but probably not as good to justify the high price without any brand factor. And they just do it, and they do it right."

- $\quad$ Expert 7: "There are companies supplying average products, many of them: The products are average, if you look at the components or ingredients, you can find the same product around the corner. But what makes that company successful is an incredible brand reputation. Those companies can charge higher prices. And customers pay for that. Often, it is a symbol of social or financial status to have that product which makes customers open their wallets."

- Expert 11: "Brand advantage is something your brand has, that your competitor doesn't. Forget the product. I am just talking about the brand. Sometimes there are 
things that you cannot explain logically, but one brand can be so much better than another brand in terms of customer perception."

2) VBP implementation in a company is more likely to be successful if the target customer is provided with a product with a highly differentiated value or acquires high perceived delivered benefits of the product itself. The experts interviewed explained this factor as follows:

- $\quad$ Expert 10: "Price differentiation requires product differentiation beforehand. Many forget that."

- $\quad$ Expert 9: "There are companies out there, which many of my clients have as their what they call 'inimitable best practice'. Companies like Apple, Google, they are so innovative that it is hardly possible to grasp how they are doing it. Every year, they reinvent their products and add features that their customers didn't know they needed."

- Expert 2: "There are large organisations that simply have the means, I mean the investment capital, to conduct market research in terms of what the target customer does not need today, but what they need tomorrow. And that is the next level. Differentiating your product based on future needs of customers. That is where the real value is generated."

The succeeding eight experts were then confronted with their perception of the two factors, and 6 out of these eight experts fully agreed to their significance in business practice. Thus, when interpreting the two factors mentioned above, two main dimensions in the implementation stage of value-based pricing were identified in this research study. Factor 1 addresses the brand dimension or the brand advantage (BA) on the market compared to existing competition. Factor 2 represents the product dimension or the delivered product benefits (DB) as perceived by the customer compared to competitive products. If both factors are quantified on a scale of $0-10$, where 0 represents the weakest score and 10 represents the highest score, a two-dimensional model can be created. The two-dimensional model then increases the chances for companies to generate a competitive edge in determining whether the implementation of VBP should be considered and whether it may increase profitability.

In the next step, the two-dimensional model was separated into four quadrants, with each of the quadrants being of similar size and weight. The created matrix now allows for the quantification of a company's position on the brand dimension scale ( $y$-axis) as well as the analysed company's product position on the product dimension scale (x-axis). The quantification then leads to recommendations based on the quadrant and the position within the matrix, leading to a possible determination of suitability for implementing value-based pricing. Thus, the new matrix is called the Value-based Pricing Determination Matrix, or VBP Determination Matrix by the authors of this study. The VBP Determination Matrix is illustrated in Figure 1 and shows the quadrants in which a company may find itself in or in-between. 
VBP DETERMINATION MATRIX

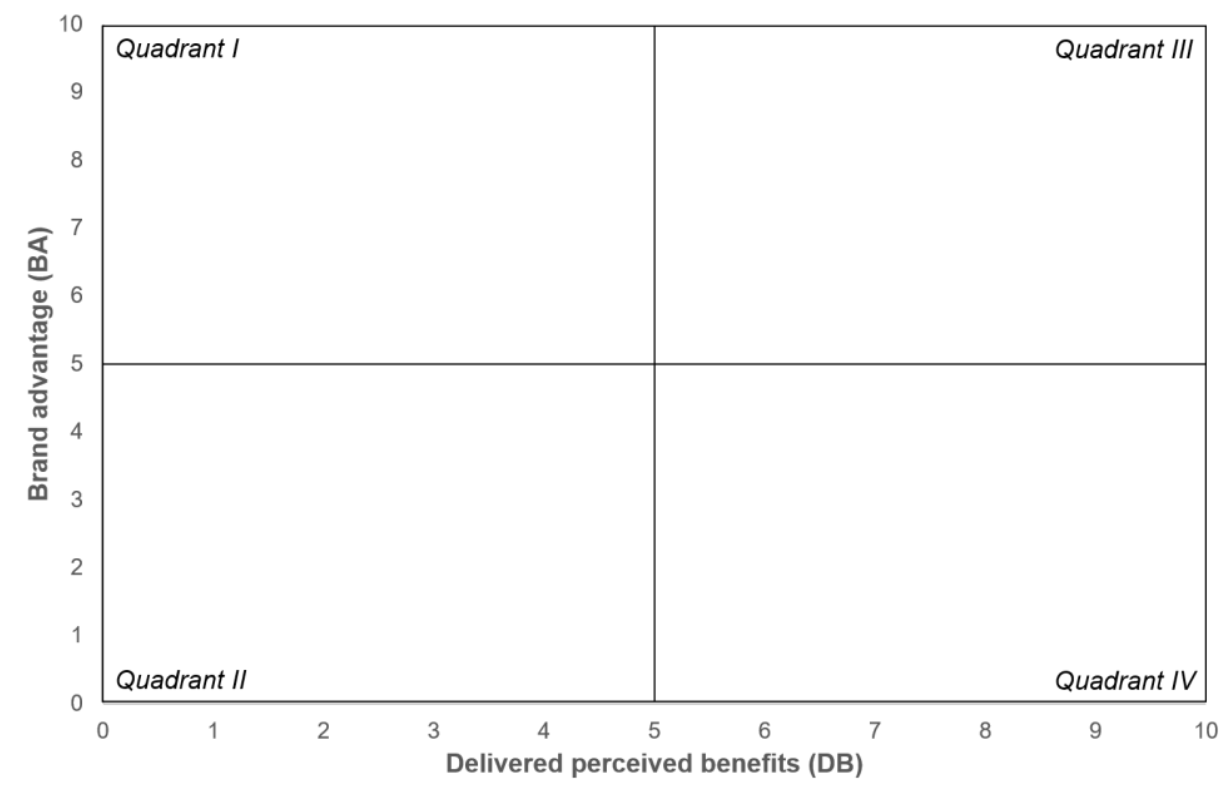

Source: own research (2020)

Referring back to chapters 1.4 and 1.5, where the two factors, brand advantage and product benefits and their assessment criteria, were reviewed with existing literature, the scores on both axes of the VBP Determination Matrix can now be addressed and how they are to be allocated.

For factor BA, we recommend using Aaker's (1996) 'Brand Equity Ten' to find the score on the $y$-axis. Our recommended approach evaluates the ten criteria described in chapter 1.4 once for its brand and once for one or more competitive brands. A subsequent comparison can be taken to identify the superior or inferior performance of the own-brand compared to competitive brands. If the competitive brand or one of the competitive brands performs better on a certain criterion based on the conducted tests with customers, this score shall be removed from its brand. The VBP Determination Matrix can certainly be used for competitors to investigate the position within the matrix relative to a competitor's position. For instance, our own company A performs better in the conducted tests with customers in 6 out of 10 criteria than a competitive brand. The score of 6 shall be allocated to factor BA. Thus, the worst value on the BA scale is 0 . The best value is 10 . This assessment has the benefits of reduced complexity in business practice and the usage of a realistic comparison between two brands under all existing market circumstances, as the customer perception within a certain market is realistically evaluated.

For factor DB, we recommend investigating the Differentiation Value and EVC based on formulas (1) and (2) in this research paper for each of the market's major competitive products individually. Thus, customers should be questioned about their perceived value for each product perceived as a serious alternative product for the customer. We suggest at least four 
products should be considered for the analysis to provide a valid relative outcome. We then recommend using a 4-steps process, where in the first step, the score of 0 (worst value) shall be allocated to the product with the lowest EVC and the score of 10 (best value) to the product with the highest EVC. This is because this matrix shall provide a guideline of the delivered benefits in relation to competitive offerings. The score-0-product shall be considered the new $0 \%$, while the score-10-product shall be considered the new $100 \%$ to develop the range within the evaluation. Within this range from $0 \%$ to $100 \%$ and the VBP Determination Matrix $x$-axis covering steps from 0 to 10 , every $10 \%$ range represents a score of 1 in the matrix. Thus, if a company scores a percentage value of $50 \%$, the score of 5 shall be allocated. If it scores $30 \%$, a score 3 shall be added. Therefore, each $10 \%$-step in the newly created range then increases the score on the DB dimension. The two product values with the highest and lowest calculated EVC shall now be fixed as DB score $=0$ and DB score $=10$, respectively. To provide an example, Table 2 shall illustrate Step 1 of the DB score allocation.

Table 2 | DB score allocation - Step 1

\begin{tabular}{ccc}
\hline Product & Calculated EVC & Highest and lowest DB score \\
\hline Our product & $€ 200.05$ & $\mathrm{X}$ \\
Competitive product 1 & $€ 185.15$ & $\mathbf{X}$ \\
Competitive product 2 & $€ 225.19$ & $\mathbf{1 0}$ (highest EVC) $=100 \%$ \\
Competitive product 3 & $€ 137.25$ & $\mathbf{0}$ (lowest EVC) $=0 \%$ \\
Competitive product 4 & $€ 192.07$ & $\mathrm{X}$ \\
Competitive product 5 & $€ 161.75$ & $\mathrm{X}$ \\
Competitive product 6 & $€ 155.12$ & $\mathrm{X}$ \\
\hline
\end{tabular}

Source: own proposed theory (2020)

Then, in Step 2, each product's EVC shall be subtracted by the score-0-product, leading to the Remaining EVC in Table 3. Subsequently, in Step 3, the Remaining EVC of each product shall be divided by the score-10-product's Remaining EVC, multiplied by 100 for a percentage amount, leading to the Relative EVC value. The Relative EVC value then shows the DB score directly if using each $10 \%$-step as an additional score of 1 on the DB dimension. We suggest rounding the percentage value to the closest $10 \%$ step to have a round DB value, but leave it open to the user to enter non-rounded DB scores alternatively and illustrate this accordingly in the VBP Determination Matrix (Step 4).

Table 3 | DB score allocation - Steps 2, 3 and 4

\begin{tabular}{cccc}
\hline Product & $\begin{array}{c}\text { Remaining EVC } \\
\text { (Step 2) }\end{array}$ & $\begin{array}{c}\text { Relative EVC value } \\
\text { (Step 3) }\end{array}$ & $\begin{array}{c}\text { DB score } \\
\text { (Step 4) }\end{array}$ \\
\hline Our product & $€ 62.80$ & $71 \%$ & 7 \\
Competitive product 1 & $€ 47.90$ & $54 \%$ & 5 \\
Competitive product 2 & $€ 87.94$ & $100 \%$ & $\mathbf{1 0}$ \\
Competitive product 3 & $€ 0$ & $\mathbf{0 \%}$ & $\mathbf{0}$ \\
Competitive product 4 & $€ 54.82$ & $62 \%$ & 6 \\
Competitive product 5 & $€ 24.50$ & $28 \%$ & 3 \\
Competitive product 6 & $€ 17.87$ & $20 \%$ & 2 \\
\hline
\end{tabular}

Source: own proposed theory (2020)

Based on this approach, it can be seen that our own product in this example can be given a DB score of 7 , which is the second-highest score among main competitive products. This 
approach allows a realistic assessment of the delivered product benefits. These results are then independent of the product price or industry, as the relative range between all products is always considered.

The VBP Determination Matrix shall be used by an executive manager of a company in any industry and should lead to a critical and self-evaluative approach to the positioning of the own company and the evaluated product on the matrix. After the two values on the BA scale and the DB scale have been recorded, subsequent recommendations for the company can be derived.

I. Quadrant I:

- Situation: Strong brand advantage on the market, weak delivered benefits of the product to the consumer.

- Recommended strategic move: Invest in R\&D to improve the innovative component of the product and move to Quadrant III or improve awareness of product benefits. If the delivered product benefits are perceived as weak by customers, the implementation of value-based pricing is not sustainable.

II. Quadrant II:

- Situation: Weak brand advantage on the market, weak delivered benefits of the product to the consumer.

- Recommended strategic move: Do not use value-based pricing. This is often the case for commodity-type products and markets. Use cost- or competitionbased pricing to get to know the market and follow competitors until investment funds are available and until product differentiation opportunities arise. Do not invest resources in implementing value-based pricing.

III. Quadrant III:

- Situation: Strong brand advantage on the market, strong delivered benefits of the product to the consumer.

- Recommended strategic move: High chances to use value-based pricing. Focus on communicating value to the customer and limit the use of cost- or competition-based pricing. Benefit from higher margins.

IV. Quadrant IV:

- Situation: Weak brand advantage on the market, strong delivered benefits of the product to the consumer.

- $\quad$ Recommended strategic move: Invest in marketing measures to improve brand advantage awareness on the market and try to move to Quadrant III.

To illustrate the calls-to-action, Figure 2 shows the full VBP Determination Matrix. 


\section{VBP DETERMINATION MATRIX}

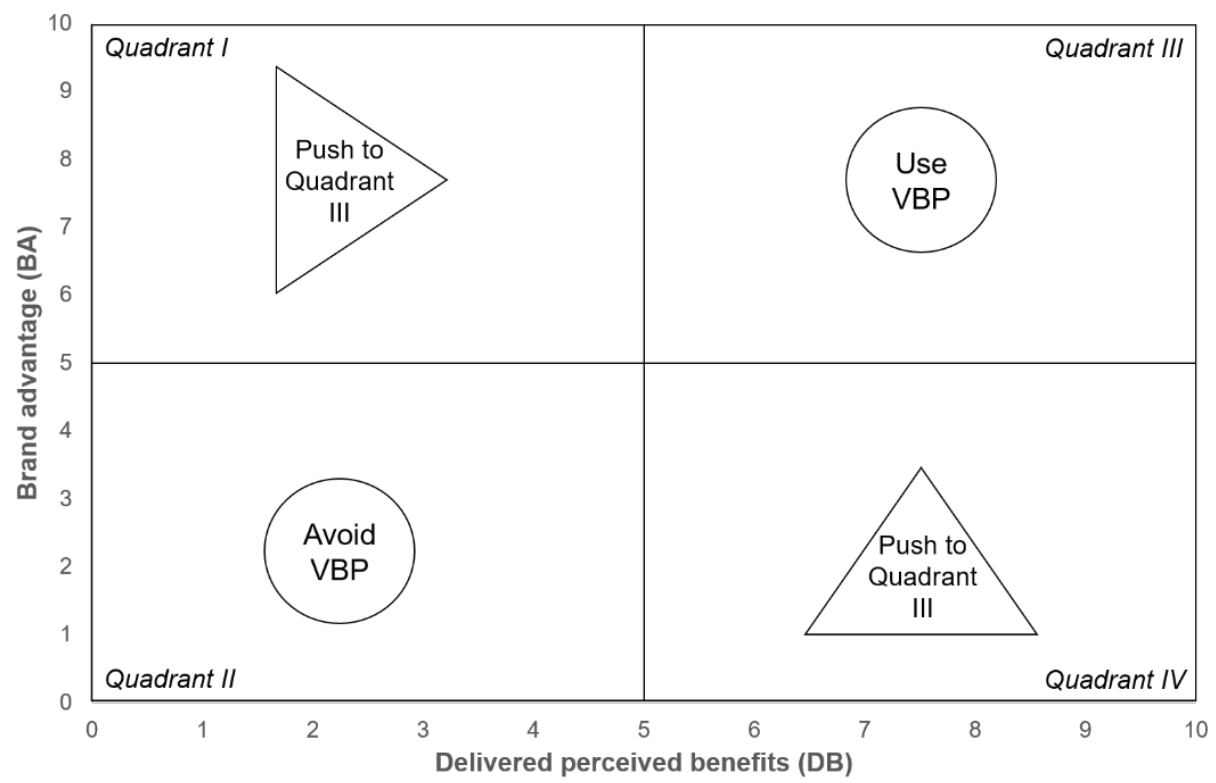

Source: own research (2020)

To provide an example of how to interpret a company's score allocation in the VBP Determination Matrix and increase the company's competitiveness through the utilisation of the model, the following paragraph provides an insight.

Company A would like to know if VBP could be a possible alternative for its product instead of using the previously utilised competition-based pricing, which currently leads to low profits.

1) The company enjoys a relatively strong brand advantage in the technology industry in Germany, with two competitors enjoying a similar reputation on the market, epitomising an oligopoly of three main companies in the market. A customer-based market analysis was conducted based on Aaker's 'Brand Equity Ten' criteria and led to a score of 6 on the BA dimension.

2) Company $A$ has recently launched a new flatscreen TV with improved pixel processing, innovative hardware, and a new high-resolution display for Ultra HD experience, delivering very strong perceived benefits to the end consumer compared to currently available competitive products. Based on Forbis and Mehta's and Tucker's 'EVC analysis', the Differentiated Value compared to competitive products is found to be quite high, leading to a percentage score of $71 \%$, thus, a score of 7 on the DB dimension.

The following illustration in Figure 3 shows Company A on the VBP Determination Matrix. 
Figure 3 | VBP Determination Matrix with calls-to-action for companies

\section{VBP DETERMINATION MATRIX}

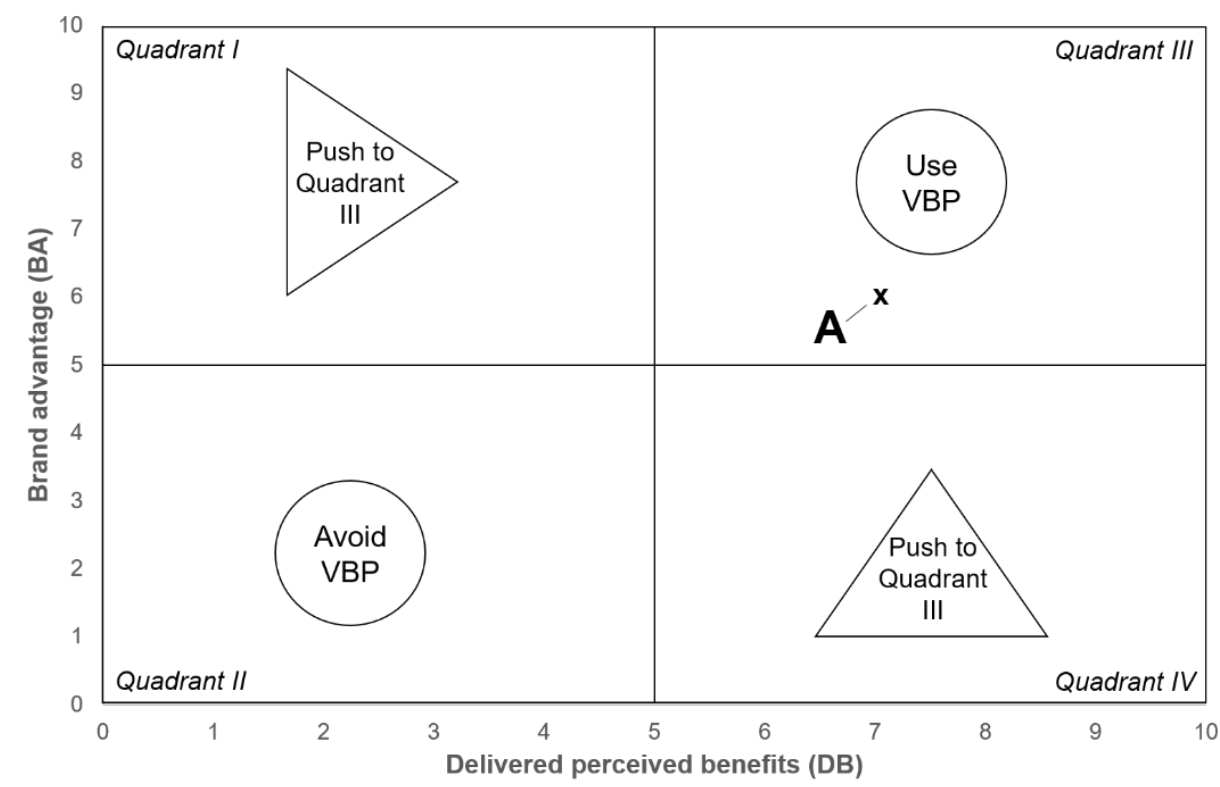

Source: own research (2020)

The analysis of Company A based on the VBP Determination Matrix is the following:

- Situation: Company A has a relatively strong brand advantage, being a major player on the market but not the most highly recognised leader on the market in terms of brand awareness. The recently launched product delivers strong perceived benefits to the customer, while competitive product 2 has a higher score in perceived benefits.

- Recommended strategic move: Company A has a high chance to implement valuebased pricing for its new flatscreen TV and, thus, it is worth to continue with analysis and assessment of other circumstances and obstacles to the VBP implementation. Company A needs to stay focused on marketing activities to increase brand awareness and further improve its brand advantage on the market. It could also be done through improved customer experience with the brand. Company A should continue to provide their highly beneficial products to enhance delivered perceived product benefits while also increasing brand awareness to move up on the brand advantage scale. Still, the implementation of VBP is recommended.

Thus, the research question can be responded to: Based on the results derived from the qualitative data collected, a theoretical framework - namely the VBP Determination Matrix has been developed to aid business practitioners in determining whether they should implement value-based pricing and to help in the pricing method selection stage. Companies comprehending and utilising the VBP Determination Matrix most likely benefit from a competitive edge in the field of pricing and in implementing value-based pricing before 
competing companies do if it represents a suitable pricing method for implementation. The use of the VBP Determination Matrix may save them time, money and effort on deeper analysis connected to the assessment of VBP implementation.

\section{Discussion}

The first author's research in his doctoral studies' scope led to the basic pillars of this research paper. So far, research has identified the benefits and the potential of value-based pricing as well as the existence of particular barriers to the implementation of value-based pricing (e.g. Anderson et al., 2010; Hinterhuber, 2008a; Hinterhuber \& Bertini, 2011; Michel \& Pfäffli, 2012; Nagle \& Müller, 2018; Reynolds, 2018; Töytäri et al., 2015, p. 54; Töytäri et al., 2017). The general need to implement value-based pricing was described by several researchers because of the high profitability if correctly implemented (Hünerberg \& Hüttmann, 2003; Piercy et al., 2010). However, no study has yet focused on deriving a theoretical framework or model to determine whether the implementation of value-based pricing is useful and should be recommended to companies or individuals. Hence, the general necessity and suitability based on a company's realistic market circumstances in any industry have not been researched yet, and a model was missing for business practitioners. This is consistent with Chenavez and Paraschiv's (2018) findings of the lack of a dynamic pricing model. However, while this research study has identified the overarching significance of the two factors brand advantage and delivered product benefits, Halttunen (2016) has rather discussed newly emerging factors like ease of use, access to the service, consumer's technological skills and others that may be added to the factors price and variety of choices. This is in contrast to this research, where it has been identified that two basic pillars are necessary for determining whether VBP may be a successful alternative to other pricing methods. Moreover, the findings from this research study in Quadrant IV of the VBP Determination Matrix suggest the investment into marketing measures to increase the customer's value perception for successful usage of VBP. This is very consistent with Reynolds' (2018) findings that suggest that marketing efforts may lead to enhanced customer perceived value, being likely to improve VBP effectiveness, partially confirming this research study's findings.

Furthermore, several research studies focused on the barriers to implement VBP in industryspecific contexts, like the consumer goods industry (Codini et al., 2012), the pharmaceutical industry (Dittmer, 2017; Pauly, 2017) or B2B markets specifically (Liinamaa et al., 2016; Töytäri et al., 2017). Thus, the barriers to implementing VBP have so far been ambiguous and highly dependent on the industry investigated. In our humble opinion, while this research certainly was needed, it was crucial to aid business practitioners from all industries with a model that may now be used more broadly and can be generalised for several markets. Therefore, instead of using an industry-specific context, this study intentionally focused on the Central European economy as a whole, in which all individuals and all companies from various industries can now evaluate themselves and their product in the VBP Determination Matrix.

The VBP Determination Matrix is a model particularly relevant for business practitioners and company executives who would like to evaluate a possible implementation or usage of valuebased pricing instead of traditional, less profitable pricing methods like cost- and competitionbased pricing. The development of the model was based on the findings from the qualitative data collection. The reasons for developing the matrix on a quadrant basis instead of a 
sextant or nonant basis are manifold and were initially based on the highly relevant quadrantbased matrices BCG matrix, Eisenhower matrix and Ansoff matrix (Bratterud et al., 2020; Duică et al., 2014; Loredana, 2017). The main objective for this matrix was to provide business practitioners with a model that is both time-efficient to understand and applicable in business practice. Thus, to reduce complexity for business practitioners and to provide direct calls-to-action to avoid losing senior management interest, a quadrant-based matrix was developed. In addition, a generalised approach to business problems was taken intentionally. Therefore, the quadrants were not given direct nouns such as 'VBP Leader', but rather the matrix was equipped with direct calls-to-action for senior management. If nonants were used, it would be more complex to provide such actionable recommendations, and management decision-making could be impeded. The utilised quadrants allow to directly identify the company's position and identify major business issues in a time-effective manner. This theoretical model is easy to use and solely requires a comprehensive understanding of the company's market and the customer's perception of the product to be sold. The easy-to-use and highly applicable model can increase management interest in the pricing method and lead to its implementation, where both the consumer and the company win in the positivesum-game of value-based pricing. Further, a major benefit is increased competitiveness for the company by providing valuable recommendations and calls-to-action for companies and executives aware of VBP but lack the knowledge to determine whether the implementation would be successful.

While the VBP Determination Matrix provides valuable contributions both to existing literature and to business practitioners, some limitations need to be addressed:

- $\quad$ First, during the qualitative data collection in the scope of this study, all 20 expert interviews were conducted via telephone. No emotions or facial expressions could be observed by the author, possibly leading to slightly flawed conclusions in comparison to face-to-face interviews. Because of experts' physical distribution across all of Germany and limitations due to coronavirus precautions, the telephone interview approach needed to be chosen.

- Second, the authors' own views and possibly biased perceptions may have influenced the interpretation of the results. The authors' main study focus was on the obstacles to the implementation of value-based pricing and how to overcome them. This main study focus, along with the professional pricing background of the first author, may have led to subconsciously biased conclusions, also in the scope of this study.

- $\quad$ Third, for the VBP Determination Matrix development, only two dimensions were used, namely the brand dimension and the product dimension. These have been used because of their relevance in literature and based on the conducted qualitative data analysis. In reality, other factors are influencing the usage of value-based pricing which needs to be addressed by further research, such as a potential impact of digitalisation: Emerging trends like big data, behavioural pricing or artificial intelligence in pricing and their connection to value-based pricing is yet to be addressed by research. Thus, the authors consider this matrix an initial indicator for determining the suitability for VBP implementation. Based on its conclusion, they recommend to deepen the analysis or reconsider the use of another pricing method instead of VBP. Still, the developed matrix gives a very good indication if resources into the implementation of VBP should be invested at all. It would be interesting to 
see in further studies a focus on digitalisation and its impact on value-based pricing implementation, potentially connected with the VBP Determination Matrix.

The authors are open to suggestions for improvement of the model and recommend other researchers to further develop it. This further research is certainly needed both in literature as well as for business practitioners to improve and accelerate the proper implementation of value-based pricing.

\section{Conclusion}

Value-based pricing has already been defined as a superior and highly profitable pricing method described in the literature review. Several barriers to implementation are rampant and lead to a very low implementation rate among companies (Hinterhuber \& Bertini, 2011). According to the interviewed pricing experts, companies are often not sure if an implementation of value-based pricing may be relevant to their own company. During the qualitative data collection stage, two main factors were identified and focused mainly on the two dimensions of brand advantage and delivered product benefits. When taking a deeper look into the two dimensions and utilising a scale of 0 to 10 in a two-dimensional model, four quadrants could be identified, each leading to substantial strategic recommendations within the Value-based Pricing Determination Matrix. This calls-to-action then allow a company to determine whether value-based pricing may be suitable or to make it a suitable alternative. A self-evaluative and critical perspective may then be easier for companies to develop pathways for future success in pricing and gradually increase profitability - based on the VBP Determination Matrix and its recommendations.

This matrix should help with the initial assessment of VBP suitability for particular products. It is, of course, needed that after a positive outcome from VBP Determination Matrix, the company needs to conduct further analysis supporting the VBP implementation, such as availability of suitable data sources (e.g. via big data collection), and availability of suitable tools (e.g. software helping to process captured customer data). However, this costly and demanding process can be avoided or postponed by companies who see their VBP implementation obstacles lie already in the core: The brand value and product value perception. These need to be addressed sooner to provide a foundation for VBP suitability determination.

\section{References}

Aaker, D. A. (1996). Measuring Brand Equity across products and markets. California Management Review, 38 (3), 102-120. Retrieved from https://www.academia.edu/7284936/Aaker_1996_Measuring_Brand_Equity_Across_Products_ and_Markets.

Anderson, J. C., \& Narus, J. A. (1998). Business Marketing: Understand what customers value. Harvard Business Review, Financial Management. Retrieved from https://hbr.org/1998/11/businessmarketing-understand-what-customers-value.

Anderson, J. C., Wouters, M., \& van Rossum, W. (2010). Why the Highest Price isn't the Best Price? MIT Sloan Management Review, 69-78.

Baker, W., Marn M., \& Zawada, C. (2010). Building a better pricing infrastructure. McKinsey Quarterly. Retrieved from https://www.mckinsey.com/business-functions/marketing-and-sales/ourinsights/building-a-better-pricing-infrastructure. 
Blois, K. J., \& Ramirez, R. (2006). Capabilities as marketable assets: A proposal for a functional categorisation. Industrial Marketing Management, 35(8), 1027-1031. http://dx.doi.org/10.1016/j.indmarman.2006.06.004.

Bosankic, L. (2016). A basic guide on cost- and value-based pricing. Retrieved from https://medium.com/@leo_pold_b/a-basic-guide-on-cost-and-value-based-pricing$66 \mathrm{e} 8 \mathrm{~d} 5 \mathrm{dad} 22 \mathrm{f}$.

Bratterud, H., Burgess, M., Fasy, B. T., Millman, D. L., Oster, T., \& Sung, E. (2020). The Sung Diagram: Revitalising the Eisenhower Matrix. In: Pietarinen AV., Chapman P., Bosveld-de Smet L., Giardino V., Corter J., Linker S. (eds) Diagrammatic Representation and Inference. Diagrams 2020. Lecture Notes in Computer Science, vol 12169. Springer, Cham. https://doi.org/10.1007/978-3-030-54249-8_43.

Bruck, L. (2010). The Price is Right ... Or Is It? Manufacturers are using value-based pricing and customer choice to generate profits. EHS Today, 3(10), F-2.

Cannon, H. M., \& Morgan, F. W. (1990). A Strategic Pricing Framework. Journal of Services Marketing, 4(2), 19-30, https://doi.org/10.1108/EUM0000000002508.

Chenavez, R., \& Paraschiv, C. (2018). Dynamic pricing for inventories with reference price effects. Economics: The Open-Access, Open-Assessment E-Journal, 12(64), 1-16. 10.5018/economicsejournal.ja.2018-64.

Codini, A., Saccani, N., \& Sicco, A. (2012) The relationship between customer value and pricing strategies: an empirical test. Journal of Product \& Brand Management, 21(7), 538-546. https://doi.org/10.1108/10610421211276321.

Collins, M., \& Parsa, H. G. (2006). Pricing strategies to maximise revenues in the lodging industry. International Journal of Hospitality Management, 25(1), 91-107. https://doi.org/10.1016/j.jhm.2004.12.009.

Creswell, J. W., \& Miller, D. L. (2000). Determining validity in qualitative inquiry. Theory into Practice, 39(3), 124-131.

Ding, W. (2007). Services Pricing through Business Value Modeling and Analysis. IEEE International Conference on Services Computing, 7380-386. https://doi.org/10.1109/SCC.2007.107.

Dittmer, D. (2017). Krebsmittel werden für viele unerschwinglich. Retrieved from https://www.ntv.de/wirtschaft/Krebsmittel-werden-fuer-viele-unerschwinglich-article20202573.html.

Dixit, A., \& Nalebuff, B. (2019). Game Theory. Retrieved from https://www.econlib.org/library/Enc/GameTheory.html.

Duică, A., Croitoru, G., Duică, M. C., \& Robescu, O. (2014). The rise and fall of BCG model. Management Challenges for sustainable development. Proceedings of the 8th International Management Conference, Bucharest, $\quad$ Romania. 2014. http://conferinta.management.ase.ro/archives/2014/pdf/13.pdf.

Flick, U., von Kardorff, E., \& Steinke, I. (2008). Qualitative Forschung. Ein Handbuch. Tenth Edition. Reinbek: Rowohlt.

Forbis, J. L., \& Mehta, N. T. (1979). Economic value to the customer. McKinsey Quarterly, 2000. Retrieved from https://www.mckinsey.com/business-functions/strategy-and-corporatefinance/our-insights/delivering-value-to-customers.

Forbis, J. L., \& Mehta, N. T. (1981). Value-based strategies for industrial products. Business Horizons, 24(3), 32-42. 
Frohmann, F. (2018). Digitales Pricing. Strategische Preisbildung in der digitalen Wirtschaft mit dem 3Level-Modell. Springer Gabler, 44-177 https://doi.org/10.1007/978-3-658-22573-5.

Golafshani, N. (2003). Understanding Reliability and Validity in Qualitative Research. The Qualitative Report, 8(4), 597-606. http://nsuworks.nova.edu/tqr/vol8/iss4/6.

Gosselin, D. P., \& Bauwen, G. A. (2006). Strategic account management: Customer value creation through customer alignment. Journal of Business \& Industrial Marketing, 21(6), 376-385. http://dx.doi.org/10.1108/08858620610690137.

Guerreiro, R., \& Amaral, J. (2018). Cost-based price and value-based price: are they conflicting approaches? Journal of Business \& Industrial Marketing, 33(3), 390-404, https://doi.org/10.1108/JBIM-04-2016-0085.

Hague, N. (2019). The Problem with Price. Retrieved from https://www.b2binternational.com/publications/pricing-research-marketing/.

Halttunen, V. (2016). Consumer behaviour in Digital Era. Retrieved from https://jyx.jyu.fi/bitstream/handle/123456789/49620/978-951-39-6642-

3_vaitos28052016.pdf?sequence $=1$.

Harris, G. (1994). International Advertising Standardization: What Do Multinationals Actually Standardise? Journal of International Marketing, 2(4), 13-30. https://doi.org/10.1177/1069031X9400200402.

Harvey, M. G. (1993). Point of View: A Model to Determine Standardisation of the Advertising Process in International Marketing. Journal of Advertising Research, 33(4), 57-64.

Hielscher, H., \& Firlus, T. (2018). Rabattaktion bei Aldi. Beginnt jetzt ein neuer Preiskampf mit Lidl? Retrieved from https://www.wiwo.de/unternehmen/handel/rabattaktion-bei-aldi-beginnt-jetzt-einneuerpreiskampf-mit-lidl/20872504.html.

Hill, J. S., \& Still, R. (1984). Adapting Products to LDC Tastes. Harvard Business Review, 62 (March/April), 92-101.

Hinterhuber, A. (2008a). Customer value-based pricing strategies: Why companies resist. Journal of Business Strategy, 29(4), 41-50. http://dx.doi.org/10.1108/02756660810887079.

Hinterhuber, A. (2008b). Value delivery and value-based pricing in industrial markets. Advances in Business Marketing and Purchasing, 14(08), 381-448. http://dx.doi.org/10.1016/S10690964(08)14011-X.

Hinterhuber, A., \& Bertini, M. (2011). Profiting when customers choose value over price. Business Strategy Review, 22(1), 46-49. https://doi.org/10.1111/j.1467-8616.2011.00727.x.

Hinterhuber, A., \& Liozu, S. M. (2012). Is it time to rethink your pricing strategy? MIT Sloan Management Review, 53(4), 69-77. http://refhub.elsevier.com/S0019-8501(17)30236-5/rf0205.

Hofer, K. M., Niehoff-Hoeckner, L. M., \& Totzek, D. (2019). Organising and implementing export pricing: Performance effects and moderating factors. Journal of International Marketing, 27(1), 74-94. https://doi.org/10.1177/1069031X18812718.

Homburg, C., Vomberg, A., Enke, M., \& Grimm, P. H. (2015), The Loss of the Marketing Department's Influence: Is It Really Happening? And Why Worry? In Hofer, K. M., Niehoff-Hoeckner, L. M., \& Totzek, D. (2019). Organising and implementing export pricing: Performance effects and moderating factors. Journal of International Marketing, 27(1), 74-94. https://doi.org/10.1177/1069031X18812718. 
Hünerberg, R., \& Hüttmann, A. (2003). Performance as a Basis for Price-setting in the Capital Goods Industry: Concepts and Empirical Evidence. European Management Journal, 21(6), 717-730. https://doi.org/10.1016/j.emj.2003.09.014.

Hung, W. T., Shang, J. K., \& Wang, F. C. (2010). Pricing determinants in the hotel industry: Quantile regression analysis. International Journal of Hospitality Management, 29(3), 378-384. https://doi.org/10.1016/j.ijhm.2009.09.001.

Indounas, K. (2009). Successful industrial service pricing. Journal of Business \& Industrial Marketing, 24(1-2), 86-96. https://doi.org/10.1108/08858620910931703.

Jerman, M., Kavčič, S. \& Kavčič, B. (2010). The Significance of Intangibles: A Comparative Analysis Between Croatia, Slovenia, Czech Republic, Germany and the USA. Economic ResearchEkonomska Istraživanja, 23(2), 60-69, https://doi.org/10.1080/1331677X.2010.11517412.

Keller, K. L. (1993). Conceptualising, measuring, and managing customer-based brand equity. Journal of Marketing, 57(1), 1-22.

Kienzler, M. (2018). Value-based pricing and cognitive biases: An overview for business markets. Industrial Marketing Management, 68(2018), 86-94. http://dx.doi.org/10.1016/j.indmarman.2017.09.028.

Kitto, S. C., Chesters, J., \& Grbich, C. (2008). Quality in qualitative research. The Medical Journal of Australia, 188, 243-6. https://www.mja.com.au/system/files/issues/188_04_180208/kit10137_fm.pdf.

Kurz, W., \& Többens, T. (2012). Global pricing survey: Managing global pricing excellence. Retrieved from https://www2.deloitte.com/content/dam/Deloitte/de/Documents/strategy/C-studie-b2bpricing_122012.pdf.

Leung, L. (2015). Validity, reliability and generalizability in qualitative research. Journal of Family Medicine and Primary Care, 4(3), 324-327. https://doi.org/10.4103/2249-4863.161306.

Liinamaa, J., Viljanen, M., Hurmerinta, A., Ivanova-Gongne, M., Luotola, H., \& Gustafsson, M. (2016). Performance-based and functional contracting in value-based solution selling. Industrial Marketing Management, 59, 37-49. http://dx.doi.org/10.1016/j.indmarman.2016.05.032.

Lincoln, Y. S., \& Guba, E. G. (1985). Naturalistic inquiry. Beverly Hills, CA: Sage.

Liozu, S. M. (2017). State of value-based-pricing survey: Perceptions, challenges, and impact. Journal of Revenue and Pricing Management, 16(1), 18-29. https://doi.org/10.1057/s41272-016-00598.

Liozu, S. M., Hinterhuber, A., Boland, R., \& Perelli, S. (2012a). The conceptualisation of value-based pricing in industrial firms. Journal of Revenue and Pricing Management, 11(1), 12-34. http://dx.doi.org/10.1057/rpm.2011.34.

Liozu, S. M., Hinterhuber, A., Perelli, S., \& Boland, R. (2012b). Mindful pricing: Transforming organisations through value-based pricing. Journal of Strategic Marketing, 20(3), 197-209. http://dx.doi.org/10.1080/0965254X.2011.643916.

Loredana, E. M. (2017). The Use of Ansoff Matrix in the field of business. Economy Series, Special Issue, 11. https://www.utgjiu.ro/revista/ec/pdf/2017-02.Volumul_2_Special/21_EcobiciL.pdf.

Mayring, P., \& Brunner, E. (2007): Qualitative Inhaltsanalyse. In Buber, Renate/ Holzmüller, Hartmut H. (2009): Qualitative Marktforschung - Konzepte, Methoden - Analysen, Wiesbaden: Gabler.

Michel, S., \& Pfäffli, P. (2012). Obstacles to implementing value-based pricing. Retrieved from https://pdfs.semanticscholar.org/d4de/3547d8efc9a9326728e0dd9c20f97510b571.pdf. 
Molinillo, S., Ekinci, Y., \& Japutra, A. (2018). A consumer-based brand performance model for assessing brand success. International Journal of Market Research, 1-33. https://core.ac.uk/download/pdf/151190366.pdf.

Nagle, T., \& Hogan, J. (2007). Is your sales force a barrier to more profitable pricing... Or is it you? Business Strategy Series, 8(5), 365-368. https://doi.org/10.1108/17515630710684484.

Nagle, T., Hogan J., \& Zale, J. (2011). The Strategy and Tactics of Pricing: A Guide to Growing more Profitably. 5th edition, Prentice Hall, New Jersey. https://lib.ugent.be/catalog/rug01:001835443.

Nagle, T., \& Müller, G. (2018). The strategy and tactics of pricing. A guide to growing more profitably. Journal of Revenue \& Pricing Management. 6th edition.

Nenonen, S., \& Storbacka, K. (2010). Business model design: conceptualising networked value cocreation. International Journal of Quality and Service Sciences, 2(1), 43-59. http://dx.doi.org/10.1108/17566691011026595.

Newcomer, K. E., Hatry, H. P., \& Wholey, J. S. (2015). Conducting semi-structured interviews. Handbook of practical program evaluation, 4, 493. https://doi.org/10.1002/9781119171386.ch19.

Neubert, M. (2017). International Pricing Strategies for Born-Global Firms. Central European Business Review, 6(3), 41-50. https://doi.org/10.18267/j.cebr.185.

Park, C. S., \& Srinivasan, V. A. (1994). Survey-Based Method for Measuring and Understanding Brand Equity and Its Extendibility. Journal of Marketing Research, 31, 271-288.

Patton, M. Q. (2002). Qualitative evaluation and research methods (3rd ed.). Thousand Oaks, CA: Sage Publications, Inc.

Pauly, M. V. (2017). The questionable economic case for value-based drug pricing in market health systems. Value in Health, 20, 278-282 http://dx.doi.org/10.1016/j.jval.2016.11.017

Piercy, N. F., Cravens, D., \& Lane, N. (2010). Thinking strategically about pricing decisions. Journal of Business Strategy, 31(5), 38-48. https://doi.org/10.1108/02756661011076309.

Provines, C. D. (2010). Overcoming organisational barriers to implementing value-based pricing in the medical devices \& diagnostics industry. Journal of Medical Marketing, 10, 37-44. https://doi.org/10.1057/jmm.2009.47.

Reynolds, H. (2018). Advantages of Value-based pricing. Retrieved from http://saasbrand.com/advantages-value-base-pricing/.

Rosenbloom, B., Larsen, T., \& Mehta, R. (1997). Global Marketing Channels and the Standardization Controversy. Journal of Global Marketing, 11(1), 49-64.

Saunders, M. N. K., \& Tosey, P. (2013). The layers of research design. Rapport. Winter 2012/2013. 5859.

Schuldt, S. (2018). Einzelhandel: Aldi und dm starten nächsten Preiskampf - Diesmal mit MarkenParfüm. Retrieved from https://www.stern.de/wirtschaft/news/aldi-und-dm-starten-naechstenpreiskampf---diesmal-koennte-douglasverlierer-sein-7857280.html.

Simon, H., \& Fassnacht, M. (2016). Preismanagement. Strategie - Analyze-Entscheidung - Umsetzung (4. Aufl.). Wiesbaden: Gabler.

Slywotzky, A. J. (1996). Value Migration. Harvard Business School Press, Boston, MA.

Stenbacka, C. (2001). Qualitative research requires quality concepts of its own. Management Decision, 39(7), 551-555. 
Strauss, A., \& Corbin, J. (1994). Grounded Theory Methodology. An Overview. Retrieved from http://www.depts.ttu.edu/education/our-

people/Faculty/additional_pages/duemer/epsy_5382_class_materials/Grounded-theorymethodology.pdf.

Subhani, M. I., \& Osman, M. A. (2009). A study on the association between brand awareness and consumer/brand loyalty for the packaged milk industry in Pakistan. Munich Personal RePEC Archive, 1-12. https://mpra.ub.uni-muenchen.de/21367/1/MPRA_paper_21367.pdf.

Terho, H., Haas, A., Eggert, A., \& Ulaga, W. (2012). It's almost like taking the sales out of selling Towards a conceptualisation of value-based selling in business markets. Industrial Marketing Management, 41(1), 174-185. http://dx.doi.org/10.1016/j.indmarman.2011.11.011.

Tohamy, N., \& Keltz, H. (2008). Building a bulletproof business case for pricing improvement initiatives. Retrieved from http://www.accenture.com/Global/Consulting/Strategy/Pricing_and_Profit_Optimization/R_and_ I/AMRInitiatives.htm.

Töytäri, P., Keränen, J., \& Rajala, R. (2017). Barriers to implementing value-based pricing in industrial markets: A micro-foundations perspective. Journal of Business Research, 76, 237-246. http://dx.doi.org/10.1016/j.jbusres.2016.04.183.

Töytäri, P., Rajala, R., \& Alejandro, T. B. (2015). Organisational and institutional barriers to value-based pricing in industrial relationships. Industrial Marketing Management, 47, 53-64. http://dx.doi.org/10.1016/j.indmarman.2015.02.005.

Tucker, C. (2010). Pricing Economic Value to the Customer. Pricing Lecture Notes. MIT Sloan School of Management, 1-6. Retrieved from https://ocw.mit.edu/courses/sloan-school-ofmanagement/15-818-pricing-spring-2010/lecture-notes/MIT15_818S10_lec02.pdf.

Walters, P. C. P., \& Toyne, B. (1989). Product Modification and Standardisation in International Markets: Strategic Options and Facilitating Policies. Columbia Journal of World Business, 14, 37-44.

The research paper passed the review process. | Received: October 19, 2020; Revised: November 24, 2020; Accepted: December 22, 2020; Pre-published online: February 21, 2021; Published in the regular issue: September 20, 2021. 